\title{
Glycemic Control and Microvascular Complications of Type 2 Diabetes among Saudis
}

\author{
Fahad S. Al-Shehri \\ University Diabetes Center, Riyadh, KSA \\ Email: fahdshar@hotmail.com
}

How to cite this paper: Al-Shehri, F.S. (2019) Glycemic Control and Microvascular Complications of Type 2 Diabetes among Saudis. Journal of Diabetes Mellitus, 9, 167-175.

https://doi.org/10.4236/jdm.2019.94016

Received: January 21, 2019

Accepted: November 15, 2019

Published: November 18, 2019

Copyright $\odot 2019$ by author(s) and Scientific Research Publishing Inc. This work is licensed under the Creative Commons Attribution International License (CC BY 4.0).

http://creativecommons.org/licenses/by/4.0/

\begin{abstract}
Objective: To study the relation between level of glycemic control and different micovascular complications of type 2 diabetes among Saudis. Patients and Methods: This hospital-based study analyzed the medical records of 343 type 2 diabetic patients attending the "University Diabetes Center" in "King Abdul-Aziz" University Hospital, in Riyadh City within 2006. Inclusion criteria comprised being adult, Saudi, type 2 diabetic, whose disease duration is more than one year, non-pregnant (for females). Results: Half of patients (50.4\%) were not controlled $\left(\mathrm{HbA}_{1 c}>8 \%\right)$. Vascular complications of diabetes were mainly retinopathy (45.8\%) or neuropathy (32.7\%). Prevalence of nephropathy was $9.9 \%$. Patients' sex, age, marital status and occupation were not significant variables as regard their control of diabetes. Patient's educational status was significantly associated with degree of diabetes control; the higher the patient's education the better the glycemic control $(\mathrm{p}=0.002)$. Moreover, the longer the duration of diabetes, the worse the glycemic control $(\mathrm{p}<0.001)$. All patients with manifest diabetes complications had worse glycemic control than those with no complications, including retinopathy (45.9\% vs. $52.7 \%$, respectively), neuropathy $(38.4 \%$ vs. $55 \%$, respectively, $\mathrm{p}=0.004)$ and nephropathy (32.4\% vs. $51.5 \%, \mathrm{p}=0.034)$. Conclusions: Glycemic control among type 2 diabetics is a real challenge that should the health care team face in tertiary-care diabetes centers in KSA. Microvascular complications are common, especially among poorly controlled cases. Recommendations: The current goal for glycemic control at the University Diabetes Center $\left(\mathrm{HbA}_{1 c}<\right.$ $8 \%$ ) should be revised. Reasons for the high prevalence of failure of diabetes control should be investigated. There should be national campaigns to raise the public awareness as regard diabetes and also screening for hyperglycemia for the sake of early diagnosis of diabetes so as to minimize the incidence of diabetes complications.
\end{abstract}

\section{Keywords}

Type 2 Diabetes, Glycemic Control, Microvascular Complications 


\section{Introduction and Aim of Study}

Diabetes mellitus (DM) is a chronic illness that requires continuous medical care, patient self-management and education, not only to prevent acute complications but also to reduce the risk of long-term complications [1]. It is a cause for a growing public health concern in both developed and developing countries. Globally, the number of people with diabetes is expected to double between 2000 and 2030 while public awareness about this disease remains low [2]. In the Kingdom of Saudi Arabia (KSA), the overall prevalence of DM is 23.7\% [3].

Despite modern treatment and self-monitoring of blood glucose, diabetes has detrimental effects on a range of health outcomes [4] [5]. Hyperglycemia is the major determinant of the risk of microvascular complications of diabetes [6]. Long-term microvascular complications of DM include retinopathy, nephropathy and neuropathy [7].

To prevent microvascular complications of diabetes, the goal for glycemic control should be as low as is feasible without undue risk for adverse events or an unacceptable burden on patients. Treatment goals should be based on a discussion of the benefits and harms of specific levels of glycemic control with the patient [8].

Above the target value $\mathrm{HbA}_{1 \mathrm{c}}$ in type 2 diabetes appear to be risk markers for early occurrence of diabetic complications [9]. Several studies have demonstrated the effects of improved glycemic control on delaying microvascular complications of diabetes [10]. Monitoring of glycemic status is considered the cornerstone of care in diabetes. Monitoring aims mainly to assess extent of success in diabetes control and to achieve the best possible blood glucose control. Measurement of glycosylated hemoglobin $\left(\mathrm{HbA}_{1 \mathrm{c}}\right)$ can quantify average glycemia over weeks and months, thereby complimenting day-to-day testing [11].

There are no fixed thresholds of glycemia for any type of complication of diabetes, the specific target value of $\mathrm{HbA}_{1 \mathrm{c}}$ for which one should aim is that the nearer to normal the $\mathrm{HbA}_{1 \mathrm{c}}$ concentration the better. Different goals for good glycemic control have been considered [12]. Generally, $\mathrm{HbA}_{1 \mathrm{c}}<8 \%$ has been put to indicate good control [11] [13] [14]. However, some studies adopted a more strict level of $\mathrm{HbA}_{1 \mathrm{c}}<7 \%$, with resulting fewer long-term microvascular complications [15] [16] [17] [18].

The Veterans Affairs Diabetes Trial is currently addressing the question of whether more intensive glycemic control will improve morbidity and mortality in older men with type 2 diabetes, in which 1792 subjects are being followed for 5 - 7 years, with a goal of $\mathrm{HbA}_{1 \mathrm{C}}$ in the intensive group of $6 \%$ [19].

This study aimed to study the relation between level of glycemic control and different micovascular complications of type 2 diabetes among Saudis.

\section{Patients and Methods}

This hospital-based research followed a retrospective study design. Data were collected from the medical records of 343 type 2 diabetic patients attending the 
"University Diabetes Center" in "King Abdul-Aziz" University Hospital, in Riyadh City within 2006. Inclusion criteria comprised being adult, Saudi, type 2 diabetic, whose disease duration is more than one year, non-pregnant (for females).

The following data were collected from patients' records: Demographic characteristics, last $\mathrm{HbA}_{1 \mathrm{c}}$ level. A poor glycemic control was considered, according to the University Diabetes Center diagnostic criteria, if $\mathrm{HbA}_{1 \mathrm{c}}>8 \%$, and microvascular complications were identified by presence of retinopathy (assessed by history of visual disturbance, history of cataract and fundus examination by an ophthalmologist), nephropathy (assessed by proteinuria or raised serum urea and creatinine after exclusion of other causes), neuropathy (assessed by a history of numbness or decreased sensation and evidence of decreased sensation or reflexes on neurological examination or evidence of electrophysiological testing).

Data analysis was carried out using the Statistical Package for Social Sciences (SPSS ver. 14.0). Descriptive statistics were applied (i.e. frequency, percentage). Proportions were compared by Chi-square Test. Significance level was set at $\mathrm{p}<$ 0.05 .

\section{Results}

Table 1 shows that slightly more than half of diabetic patients were females (53.1\%), about three fourths aged 41 - 60 years (72.3\%), most patients were married (95\%), almost one third of patients were illiterate (35\%), while almost two thirds were not working (61.2\%). More than half of patients (53.9\%) were diagnosed since 10 - 20 years. Half of patients (50.4\%) were not controlled (i.e. their $\left.\mathrm{HbA}_{1 \mathrm{c}}>8 \%\right)$. Vascular complications of diabetes were mainly retinopathy (45.8\%) or neuropathy (32.7\%). Prevalence of nephropathy was $9.9 \%$.

Table 2 shows that patients' sex, age, marital status and occupation were not significant variables as regard their control of diabetes. Patient's educational status was significantly associated with degree of diabetes control, the higher the patient's education the better the glycemic control $(p=0.002)$. Moreover, the longer the duration of diabetes, the worse the glycemic control ( $p<0.001)$.

Table 3 shows that all patients with manifest diabetes complications had worse glycemic control than those with no complications, including retinopathy ( $45.9 \%$ vs. $52.7 \%$, respectively), neuropathy ( $38.4 \%$ vs. $55 \%$, respectively, $\mathrm{p}=$ $0.004)$ and nephropathy $(32.4 \%$ vs. $51.5 \%, \mathrm{p}=0.034)$.

\section{Discussion}

This study showed that half of type 2 diabetic patients were not controlled. This finding reflects the challenge of diabetes control in specialized tertiary-care diabetes centers. In Jeddah, KSA, 77\% of type 2 Saudi diabetic patients attending King Abdul-Aziz University Hospital have poor glycemic control $\left(\mathrm{HbA}_{1 \mathrm{c}}>8 \%\right)$ [11]. In Al-Ain District, United Arab Emirates (UAE), 62.4\% of diabetic patients have poor glycemic control [7]. In South Africa, A good control among 20.1\% of 
type 2 black diabetics attending the diabetic clinic at a peri-urban hospital was noticed [20]. In Trinidad \& Tobago, a poor glycemic control among 55.3\% of type 2 diabetics was noticed [17].

Table 1. Characteristics of study sample $(n=343)$.

\begin{tabular}{|c|c|c|}
\hline Variables & No. & $\%$ \\
\hline \multicolumn{3}{|l|}{ Sex: } \\
\hline - Females & 182 & 53.1 \\
\hline - Males & 161 & 46.9 \\
\hline \multicolumn{3}{|l|}{ Age groups (in years): } \\
\hline$\bullet \leq 40$ & 45 & 13.1 \\
\hline - $41-60$ & 248 & 72.3 \\
\hline$\bullet>60$ & 50 & 14.6 \\
\hline \multicolumn{3}{|l|}{ Marital status: } \\
\hline - Not married & 17 & 5.0 \\
\hline - Married & 326 & 95.0 \\
\hline \multicolumn{3}{|l|}{ Education: } \\
\hline - Illiterate & 120 & 35.0 \\
\hline - School (primary/intermediate/secondary) & 161 & 46.9 \\
\hline • University & 62 & 18.1 \\
\hline \multicolumn{3}{|l|}{ Occupation: } \\
\hline - Governmental & 79 & 23.0 \\
\hline - Business & 16 & 4.7 \\
\hline - Professional & 38 & 11.1 \\
\hline - Unemployed/housewife/student/retired & 210 & 61.2 \\
\hline \multicolumn{3}{|l|}{ Duration of diabetes (years) } \\
\hline$\bullet<10$ & 109 & 31.8 \\
\hline - 10 - 20 & 185 & 53.9 \\
\hline$\bullet>20$ & 49 & 14.3 \\
\hline \multicolumn{3}{|l|}{ Glycemic control } \\
\hline - $\mathrm{HbA}_{1 \mathrm{C}} \leq 8 \%$ & 170 & 49.6 \\
\hline - $\mathrm{HbA}_{1 \mathrm{C}}>8 \%$ & 173 & 50.4 \\
\hline \multicolumn{3}{|l|}{ Diabetes complications } \\
\hline - Retinopathy & 157 & 45.8 \\
\hline - Neuropathy & 112 & 32.7 \\
\hline - Nephropathy & 34 & 9.9 \\
\hline - Diabetic foot & 19 & 5.5 \\
\hline
\end{tabular}


Table 2. Distribution of level of diabetes control according to patients' characteristics.

\begin{tabular}{|c|c|c|c|c|c|}
\hline \multirow[b]{2}{*}{ Variables } & \multicolumn{2}{|c|}{$\mathrm{HbA}_{1 \mathrm{c}} \leq 8 \%(\mathrm{n}=170)$} & \multicolumn{2}{|c|}{$\mathrm{HbA}_{1 \mathrm{c}}>8 \%(\mathrm{n}=173)$} & \multirow{2}{*}{$\begin{array}{l}\mathrm{p} \\
\text { Value }\end{array}$} \\
\hline & No. & $\%$ & No. & $\%$ & \\
\hline \multicolumn{6}{|l|}{ Sex: } \\
\hline - Females & 90 & 49.5 & 92 & 50.5 & \\
\hline - Males & 80 & 49.7 & 81 & 50.3 & 1.000 \\
\hline \multicolumn{6}{|c|}{ Age groups (in years): } \\
\hline$\bullet \leq 40$ & 20 & 44.4 & 25 & 55.6 & \\
\hline - $41-60$ & 128 & 51.6 & 120 & 48.4 & \\
\hline$\bullet>60$ & 22 & 44.0 & 28 & 56.0 & 0.471 \\
\hline \multicolumn{6}{|l|}{ Marital status: } \\
\hline - Not married & 6 & 35.3 & 11 & 64.7 & \\
\hline - Married & 164 & 50.3 & 162 & 49.7 & 0.320 \\
\hline \multicolumn{6}{|l|}{ Education: } \\
\hline - Illiterate & 46 & 38.3 & 74 & 61.7 & \\
\hline - School & 84 & 52.2 & 77 & 47.8 & \\
\hline - University & 40 & 64.5 & 22 & 35.5 & 0.002 \\
\hline \multicolumn{6}{|l|}{ Occupation: } \\
\hline - Governmental & 42 & 53.2 & 37 & 46.8 & \\
\hline - Business & 10 & 62.5 & 6 & 37.5 & \\
\hline - Professional & 23 & 60.5 & 15 & 39.5 & \\
\hline • Unemployed & 95 & 45.2 & 115 & 54.8 & 0.181 \\
\hline \multicolumn{6}{|c|}{ Duration of diabetes } \\
\hline$\bullet<10$ years & 71 & 65.1 & 38 & 34.9 & \\
\hline • 10 - 20 years & 82 & 44.3 & 103 & 55.7 & \\
\hline - $>20$ years & 17 & 34.7 & 32 & 65.3 & $<0.001$ \\
\hline
\end{tabular}

Table 3. Distribution of microvascular complications according to level of diabetes control.

\begin{tabular}{|c|c|c|c|c|c|}
\hline \multirow[b]{2}{*}{ Diabetes complications } & \multicolumn{2}{|c|}{$\mathrm{HbA}_{1 \mathrm{c}} \leq 8 \%(\mathrm{n}=170)$} & \multicolumn{2}{|c|}{$\mathrm{HbA}_{1 \mathrm{c}}>8 \%(\mathrm{n}=173)$} & \multirow{2}{*}{$\begin{array}{l}\mathrm{p} \\
\text { Value }\end{array}$} \\
\hline & No. & $\%$ & No. & $\%$ & \\
\hline \multicolumn{6}{|l|}{ - Retinopathy } \\
\hline - Absent & 98 & 52.7 & 88 & 47.3 & \\
\hline - Present & 72 & 45.9 & 85 & 54.1 & 0.208 \\
\hline \multicolumn{6}{|l|}{ - Neuropathy } \\
\hline - Absent & 127 & 55.0 & 104 & 45.0 & \\
\hline - Present & 43 & 38.4 & 69 & 61.6 & 0.004 \\
\hline \multicolumn{6}{|l|}{ - Nephropathy } \\
\hline - Absent & 159 & 51.5 & 150 & 48.5 & \\
\hline - Present & 11 & 32.4 & 23 & 67.6 & 0.034 \\
\hline
\end{tabular}


The present study showed high prevalence rates of microvascular complications among type 2 diabetics. These were mainly retinopathy (45.8\%) or neuropathy (32.7\%), while the prevalence of nephropathy was $9.9 \%$.

In Jeddah, neuropathy occupied the highest rank among complications of diabetes (56.9\%), followed by retinopathy (49.2\%) and nephropathy (30.8\%) [11]. In Kuwait, prevalence of retinopathy among type 2 diabetic patients is $40 \%$ [14]. In UAE, a high prevalence of nephropathy (61.2\%) is among diabetic patients [7]. In Iran, retinopathy prevalence rate of $39.3 \%$ among type 2 diabetics and the prevalence of microalbuminuria and macroalbuminuria was $25.9 \%$ and $14.5 \%$ respectively [21]. In Turkey $60 \%$ of type 2 diabetics have neuropathy [22]. In Washington, USA, the main microvascular complications among type 2 diabetic patients were neuropathy (63\%), retinopathy (18\%) and nephropathy (6\%) [23].

The variation in prevalence rates of different microvascular complications could be the result of different diagnostic methodologies used, or population characteristics differences.

The present study showed that some patients' personal characteristics (i.e. sex, age, marital status and occupation) were not significant variables as regard their control of diabetes. However, patients' educational status was significantly associated with their diabetes control, i.e. the higher the education status, the better the glycemic control. Moreover, this study showed that the longer the duration of diabetes, the worse its control $(\mathrm{p}<0.001)$.

The glycemic control among type 2 diabetics was poor irrespective of sex, duration, educational status, with recommended target values not being achieved in the majority of patients [20]. The literacy is a significant effect-modifier in determining diabetes control in a disease management program; the patients with lower literacy are more likely to achieve goal glycemic control [24]. However, No relation between educational status of diabetic patients and their glycemic control [25].

The present study showed that patients with manifest microvascular complications had significantly less diabetes control than those with no microvascular complications, including neuropathy $(38.4 \%$ vs. $55 \%$, respectively, $\mathrm{p}=0.004)$, and nephropathy $(32.4 \%$ vs. $51.5 \%, \mathrm{p}=0.034)$. Patients with retinopathy had less glycemic control than those with no retinopathy, though not statistically significant $(45.9 \%$ vs. $52.7 \%$, respectively, $\mathrm{p}=0.208)$.

Similar results were reported by several studies. The poor glycemic control among type 2 diabetics is a major risk factor for developing nephropathy [26]. Poor glycemic control is a significant risk factor for neuropathy among type 2 diabetics [22]. As regard risk factors for retinopathy, the longer duration of diabetes was the most significant independent factors associated with any retinopathy and sight-threatening retinopathy [14].

The lack of significant difference among patients of the present study as regard glycemic control between diabetics who developed retinopathy and those who did not may be explained by the fact that retinopathy is an early complication among type 2 diabetics, which is significantly associated with duration of 
disease. In type 2 diabetes, $21 \%$ of patients have retinopathy at the time of first diagnosis of diabetes and that $>60 \%$ of patients have retinopathy during the first 2 decades of disease [27].

The high prevalence of retinopathy, irrespective of the glycemic control, among diabetics of the current series, can be explained by the results of a national Saudi study which show that, despite the readily available access to healthcare facilities in KSA, a large proportion of diabetics (27.9\%) were unaware of having DM, hence their late presentation and the high prevalence of DM-related complications [3].

\section{Conclusion}

Glycemic control among type 2 diabetics is a real challenge that should the health care team face in tertiary-care diabetes centers in KSA. Microvascular complications are common, especially among poorly controlled cases.

\section{Recommendations}

The current goal for glycemic control at the University Diabetes Center $\left(\mathrm{HbA}_{1 c}<\right.$ $8 \%)$ should be revised. Reasons for the high prevalence of failure of diabetes control should be investigated. There should be national campaigns to raise the public awareness as regard diabetes and also screening for hyperglycemia for the sake of early diagnosis of diabetes so as to minimize the incidence of diabetes complications.

\section{Conflicts of Interest}

The author declares no conflicts of interest regarding the publication of this paper.

\section{References}

[1] American Diabetes Association (2003) Standards of Medical Care for Patients with Diabetes Mellitus. Diabetes Care, 26, S33-S50. https://doi.org/10.2337/diacare.26.2007.S33

[2] Eljedia, A., Mikolajczyk, R.T., Kraemer, A. and Laaser, U. (2006) Health-Related Quality of Life in Diabetic Patients and Controls without Diabetes in Refugee Camps in the Gaza Strip: A Cross-Sectional Study. BMC Public Health, 6, 268. https://doi.org/10.1186/1471-2458-6-268

[3] Al-Nozha, M.M., Al-Maatouq, M.A., Al-Mazrou, Y.Y., Al-Harthi, S.S., Arafah, M.R., Khalil, M.Z., Khan, N.B., Al-Khadra, A., Al-Marzouki, K., Nouh, M.S., Abdullah, M., Attas, M., Al-Shahid, M.S. and Al-Mobeireek, A. (2004) Diabetes Mellitus in Saudi Arabia. Saudi Medical Journal, 25, 1603-1610.

[4] Harris, M.I. (2000) Health Care and Health Status and Outcomes for Patients with Type 2 Diabetes. Diabetes Care, 23, 754-758. https://doi.org/10.2337/diacare.23.6.754

[5] Reddy, S.S. (2000) Health Outcomes in Type 2 Diabetes. International Journal of Clinical Practice, Supplement, 113, 46-53.

[6] Juutilainen, A., Lehto, S., Ronnemaa, T., Pyorala, K. and Laakso, M. (2007) Retino- 
pathy Predicts Cardiovascular Mortality in Type 2 Diabetic Men and Women. Diabetes Care, 30, 292-299. https://doi.org/10.2337/dc06-1747

[7] Al-Maskari, F., El-Sadig, M. and Norman, J.N. (2007) The Prevalence of Macrovascular Complications among Diabetic Patients in the United Arab Emirates. Cardiovascular Diabetology, 6, 24. https://doi.org/10.1186/1475-2840-6-24

[8] Qaseem, A., Vijan, S., Snow, V., Cross, J.T., Weiss, K.B. and Owens, D.K. (2007) Clinical Efficacy Assessment Subcommittee of the American College of Physicians. Glycemic Control and Type 2 Diabetes Mellitus: The Optimal Hemoglobin a1c Targets. A Guidance Statement from the American College of Physicians. Annals of Internal Medicine, 147, 417-422.

https://doi.org/10.7326/0003-4819-147-6-200709180-00012

[9] Svensson, M., Sundkvist, G., Arnqvist, H.J., Bjork, E., Goran, B., Bolinder, J., Henricsson, M., Nystrom, L., Torffvit, O., Waernbaum, I., Ostman, J. and Eriksson, J.W. (2003) Signs of Nephropathy May Occur Early in Young Adults with Diabetes Despite Modern Diabetes Management: Results from the Nationwide Population-Based Diabetes Incidence Study in Sweden (DISS). Diabetes Care, 26, 2903-2909. https://doi.org/10.2337/diacare.26.10.2903

[10] Skyler, J.S. (2004) Effects of Glycemic Control on Diabetes Complications and on the Prevention of Diabetes. Clinical Diabetes, 22, 162-166.

https://doi.org/10.2337/diaclin.22.4.162

[11] Al-Ghamdi, A.A. (2004) Role of HbA1c in Management of Diabetes Mellitus. Saudi Medical Journal, 25, 342-345.

[12] Stratton, I.M., Adler, A.I., Neil, H.A.W., Matthews, D.R., Manley, S.E., Cull, C.A., Hadden, D., Turner, R.C. and Holman, R.R. (2000) Association of Glycemia with Macrovascular and Microvascular Complications of Type 2 Diabetes (UKPDS 35): Prospective Observational Study. BMJ, 321, 405-412. https://doi.org/10.1136/bmj.321.7258.405

[13] Okosun, I.S. and Dever, G.E.A. (2002) Abdominal Obesity and Ethnic Differences in Diabetes Awareness, Treatment, and Glycemic Control. Obesity Research, 10, 1241-1250. https://doi.org/10.1038/oby.2002.169

[14] Al-Adsani, A.M. (2007) Risk Factors for Diabetic Retinopathy in Kuwaiti Type 2 Diabetic Patients. Saudi Medical Journal, 28, 579-583.

[15] DCCT/EDIC Research Group (2000) Retinopathy and Nephropathy in Patients with Type 1 Diabetes Four Years after a Trial of Intensive Therapy. The New England Journal of Medicine, 342, 381-389. https://doi.org/10.1056/NEJM200002103420603

[16] El-Kebbi, I.M., Ziemer, D.C., Cook, C.B., Miller, C.D., Gallina, D.L. and Phillips, L.S. (2001) Comorbidity and Glycemic Control in Patients with Type 2 Diabetes. Archives of Internal Medicine, 161, 1295-1300. https://doi.org/10.1001/archinte.161.10.1295

[17] Apparico, N., Clerk, N., Henry, G., Seale, J., Sealy, R., Ward, S. and Mungrue, K. (2007) How Well Controlled Are Our Type 2 Diabetic Patients in 2002? An Observational Study in North and Central Trinidad. Diabetes Research and Clinical Practice, 75, 301-305. https://doi.org/10.1016/j.diabres.2006.06.026

[18] Maraldi, C., Volpato, S., Penninx, B.W., Yaffe, K., Simonsick, E.M., Strotmeyer, E.S., Cesari, M., Kritchevsky, S.B., Perry, S., Ayonayon, H.N. and Pahor, M. (2007) Diabetes Mellitus, Glycemic Control, and Incident Depressive Symptoms among 70- to 79-Year-Old Persons: The Health, Aging, and Body Composition Study. Archives of Internal Medicine, 167, 1137-1144. 
https://doi.org/10.1001/archinte.167.11.1137

[19] Abraira, C., Duckworth, W., McCarren, M., Emanuele, N., Arca, D., Reda, D. and Henderson, W. (2003) The Veterans Affairs Diabetes Trial (VADT). Cooperative Study of Glycemic Control and Complications in Diabetes Mellitus Type 2: Design of the Cooperative Study on Glycemic Control and Complications in Diabetes Mellitus Type 2. Journal of Diabetes and Its Complications, 17, 314-322. https://doi.org/10.1016/S1056-8727(02)00277-5

[20] Erasmus, R.T., Blanco, E.B., Okesina, A.B., Gqweta, Z. and Matsha, T. (1999) Assessment of Glycaemic Control in Stable Type 2 Black South African Diabetics Attending a Peri-Urban Clinic. Postgraduate Medical Journal, 75, 603-606. https://doi.org/10.1136/pgmj.75.888.603

[21] Manaviat, M.R., Afkhami, M. and Shoja, M.R. (2004) Retinopathy and Microalbuminuria in Type II Diabetic Patients. BMC Ophthalmology, 4, 9. https://doi.org/10.1186/1471-2415-4-9

[22] Börü, U.T., Alp, R., Sargin, H., Koçer, A., Sargin, M., Lüleci, A. and Yayla, A. (2004) Prevalence of Peripheral Neuropathy in Type 2 Diabetic Patients Attending a Diabetes Center in Turkey. Endocrine Journal, 51, 563-567.

https://doi.org/10.1507/endocrj.51.563

[23] Schellhase, K.G., Koepsell, T.D. and Weiss, N.S. (2005) Glycemic Control and the Risk of Multiple Microvascular Diabetic Complications. Family Medicine, 37, 125-130.

[24] Rothman, R., Malone, R., Bryant, B., Horlen, C., DeWalt, D. and Pignone, M. (2004) The Relationship between Literacy and Glycemic Control in a Diabetes Disease-Management Program. The Diabetes Educator, 30, 263-273. https://doi.org/10.1177/014572170403000219

[25] Morris, N.S., MacLean, C.D. and Littenberg, B. (2006) Literacy and Health Outcomes: A Cross-Sectional Study in 1002 Adults with Diabetes. Family Practice, 7, 49. https://doi.org/10.1186/1471-2296-7-49

[26] Forsblom, C.M., Groop, P.H., Ekstrand, A., Tötterman, K.J., Sane, T., Saloranta, C. and Groop, L. (1998) Predictors of Progression from Normoalbuminuria to Microalbuminuria in NIDDM. Diabetes Care, 21, 1932-1938. https://doi.org/10.2337/diacare.21.11.1932

[27] Fong, D.S., Aiello, L., Gardner, Th., King, G., Blankenship, G., Cavellarano, J., Ferris, F.L. and Klein, R. (2004) Retinopathy in Diabetes. Diabetes Care, 27, S84-S87. https://doi.org/10.2337/diacare.27.2007.S84 